\title{
SHIMI, THE SCEPTICAL: SCEPTICAL VOICES IN AN EARLY MODERN JEWISH, ANTI-CHRISTIAN POLEMICAL DRAMA BY MATITYAHU NISSIM TERNI
}

\author{
Károly Dániel Dobos*
}

\begin{abstract}
It is a truism that Jewish polemical/apologetic texts have been written since Late Antiquity with the main purpose of strengthening the faint-hearted members of Jewish communities throughout the globe. Hence the existence of this kind of text implicitly suggests the presence of some form of "religious scepticism" or feeling of uncertainty in the ranks of the Jewish population. On the other hand, since the beginning of the early modern period a radical change can be felt in the genre. The sceptical figure, who had been present previously only hidden in the background of the texts, now came forth from behind the scenes, and took a clearly identifiable shape, like Shimi, one of the protagonists of the polemical drama, written by the Italian playwright Matityahu Nissim Terni (17451810), entitled Derech Emunah ("The Way of Faith"). In this paper an attempt will be made to analyse Terni's drama as a very sensitive psychological portrayal of the complex personality of an average Italian Jew of the ghetto age, reconciling successfully the technical requirements of contemporary dramaturgy with the specific values, expectations and tantalizing questions of the Jewish community of his age.
\end{abstract}

\section{Introduction}

In the year 1782, on a sunny, early summer morning, the students of the Pesaro yeshiva, named Somech Noflim (סומך נופלים, "Supporter of the Fallen") were running excitedly up and down in the courtyard, wedged between the surrounding houses. Expecting the impending holiday of Shavuot they were preparing a theatrical performance. Indeed, it must have been a rare event in the life of an average yeshiva bocher! But the students learning in the Pesaro yeshiva had every chance to get used to watching theatre plays and making theatre, since one of their instructors in the yeshiva, Rabbi Matityahu Nissim (Donato) ben Jacob Israel Terni (1745 -c. 1810) was a prolific dramatist of his age. ${ }^{1}$

\footnotetext{
* Associate Professor of Jewish Studies at the Pazmany Peter Catholic University of Hungary, Research Fellow at the University of Vienna, Institute of Jewish Studies. Email: dobos.karoly@btk.ppke.hu

The author wishes to thank the financial support of the Anniversary Fund of the National Bank of Austria (Jubiläumsfonds der Österreichischen Nationalbank, project number: 16099: "Jüdisch-christiliche Polemik: Akkulturation und Modernisierung”), which enabled him to prepare this essay.

${ }^{1}$ On the author and his plays, see Asher Salah, La République des lettres: Rabbins, écrivains et médecins juifs en Italie au XVIII siècle (Leiden: Brill, 2007), 627-629, and Dvora Bregman's introduction to her edition of Terni's six theater plays. Dvora Bregman, ed., The Glory of Sinai: The Dramatic Works of Matityahu Nissim (Donato) Terni [in Hebrew] (Jerusalem: The Ben Zvi Institute and the Hebrew University of Jerusalem, 2003), 9-12. Terni's dramas were performed in the Pesaro Talmud Torah in the course of more than a decade. See Bregman, The Glory, v-vi.
} 


\section{Terni and his drama}

We have only very few pieces of information about this interesting personality of the age of the ghetto. ${ }^{2}$ He was born in 1745 in the Italian Adriatic seaport Ancona, belonging at that time to the Papal States. During his life he served as a rabbi and a posek (פוסק, "decisor") in different Italian towns, like Firenze, Urbino, Senigallia, or the abovementioned Pesaro. His rabbinical responsa and his poems were eagerly copied by his contemporaries. He must have been active in the politics of his days, too, because in the year 1799 he was arrested for a few days on charges of pro-French political activity during the Napoleonic occupation of Northern Italy.

His drama, whose premiere was being prepared in 1782, was written twelve years earlier, and bore the Hebrew title Derech Emunah ("The Way of Faith"). ${ }^{3}$ The composition must have been quite popular in his time. The main proof of its popularity is the eleven manuscript copies of the text, preserved in different, Hebrew language manuscript collections of polemical texts. ${ }^{4}$ Derech Emunah is far from being the very first Jewish drama, it is not even the first written in Hebrew, ${ }^{5}$ yet it is a rather peculiar representative of the genre - although polemics are prone to be written in dialogue form, to the best of my knowledge, until this time it is the only known Jewish polemical drama, performed by real actors on a stage. On its title page the theatre play is characterized as ke-en vikkuah (עיכין) ויכוח, as a polemical dialogue) between two friends, named Shimi (שמעי) and Rei (רעי), respectively. ${ }^{6}$ Shimi is described in the short guide of instructions for the performers, found also on the title page of the text, as someone who maqsheh qushyot (מקשה קושיות, asks difficult questions), mevaqshe raatenu (מבקשי רעתנו, seeking to destroy the Jewish religion), while his friend, Rei, tries to defend it with reasoned logic and rational arguments. ${ }^{8}$

Terni's drama does not stand out in the long history of Jewish anti-Christian polemics due to the philosophical depth of its dialogues. The arguments Rei deployed in defence of

\footnotetext{
2 An unbiased historical portray of the Italian ghetto period, with its oppositely acting centrifugal and centripetal forces, can be obtained from the book of Kenneth Stow, Theater of Acculturation: The Roman Ghetto in the Sixteenth Century (Seattle: The University of Washington Press, 2001). The vantage point of a contemporary eyewitness is preserved in the autobiographical diary of Yehuda Aryeh Modena (1571-1648). See his The Autobiography of a Seventeenth-Century Venetian Rabbi: Leon Modena's Life of Judah, trans. and ed., Mark R. Cohen (Princeton: Princeton University Press, 1988).

${ }^{3}$ It was Hayim Schirmann, the well-known authority on medieval Hebrew poetry, who first drew the scholarly world's attention to the dramas of Terni. See his Studies in the History of Hebrew Poetry and Drama [in Hebrew], 2 vols. (Jerusalem: Mosad Bialik, 1979), 2:78. Terni's polemical drama was first published by Yonah David in the pages of the Hebrew language journal Zehut. See his “M. N. Terni's 'Derech Emunah”' [in Hebrew], Zehut 2 (1982): 267-286. This was later re-edited in Bregman, The Glory, 117-139.

${ }^{4}$ Terni's polemical drama can be found in the following mss.: (1) Cincinnati, Hebrew Union College (CIN 397, 68r-76v); (2) Jerusalem, Ben Zvi Institute (JER BEN ZVI 4068, 1r $-4 v$ ), with punctuation; (3) London, British Library (LON BL 1105, on 34r-40r); (4) Moscow, Russian State Library, Günzburg Collection (MOS 161, 41 r-54v); (5) Moscow, Russian State Library, Günzburg Collection (MOS 161, 281r-286v), with punctuation; (6) Moscow, Russian State Library, M. Günzburg (MOS 280, 208r-222v), with punctuation; (7) Moscow, Russian State Library, Günzburg Collection (MOS 360, 195-206v); (8) New York, Columbia University (NY COLUM X 893 M 692, 1r-11v); (9) New York, Jewish Theological Seminary (NY JTS 1274, 52v-53r), a fragment; (10) New York, Jewish Theological Seminary (NY JTS 1511, 1r-11v); (11) New York, Jewish Theological Seminary (NY JTS 2235, 37r_43r).

5 The first Jewish drama was written in Greek in Alexandria by the $2^{\text {nd }}$ century BCE dramatist, named Ezekiel, the Tragedian; the first Hebrew language drama was Moses ben Mordechai Zacuto's (c. 1620-1697) play, entitled Yesod Olam ("The Eternal Foundation") in 1642.

${ }^{6}$ Bregman, The Glory, 117-118.

7 מבקשי רעתנו 7.

${ }_{8}$ Bregman, The Glory, 117-118.
} 
Judaism were quite conventional. ${ }^{9}$ Not even its imitation of the literary style of Pietro Metastasio (1698-1782), recognized in his age as a standard for plays and librettos, is particularly attractive for the modern reader. ${ }^{10}$ However, the entire work can be characterized as a very sensitive psychological portrayal of the feelings, the fears and hopes of an average Italian Jew of the ghetto age, reconciling successfully the technical requirements of contemporary dramaturgy with the specific values, expectations and tantalizing questions of the Jewish community of his age.

\section{The names of the protagonists and the allusions they evoke}

Before getting down to cases, let us try to put across the author's choice of the names of his characters which seems to be far from trivial. The text of the theatre play is written in Biblical Hebrew, so we cannot be overly wrong if we try to identify the forerunners of the drama's protagonists among the personalities mentioned in the Bible. Indeed, the name of Shimi occurs several times in the Bible, ${ }^{11}$ but the only real personality whose story is told on the pages of 2 Samuel and 1 Kings was a contemporary of David. ${ }^{12}$ Shimi was an enemy of King David; he first appeared on the scene in Chapter 16 of 2 Samuel. ${ }^{13}$ Due to Absalom's revolt, told of in Chapter 15, David had to flee to the countryside; we met him in Bahurim marching along with his exhausted followers on a bleak hillside. Suddenly an angry man appeared on the opposite hillside, continually cursing and casting stones at David, moving along the company for a while and shouting to him: "Begone, begone, thou man of blood, and base fellow, the LORD hath returned upon thee all the blood of the house of Saul." 14 The cursing man was Shimi, the son of Gera, who belonged to the house of Shaul, the former king, whose dynasty had been deprived of the throne by King David. After the death of Absalom we meet Shimi in a completely different situation, pleading for clemency before the triumphant king David, returning to Judah. ${ }^{15}$ He was first pardoned by David, but later the ageing king suggested killing him to his successor, Solomon. ${ }^{16}$ Solomon allowed Shimi to live in Jerusalem for a while in a kind of house arrest, but finally, when he

\footnotetext{
${ }^{9}$ On the main topics of Jewish-Christian controversy, see Daniel J. Lasker, Jewish Philosophical Polemics against Christianity in the Middle Ages, 2nd ed. (Oxford: The Littman Library of Jewish Civilization, 2007).

${ }^{10}$ However, as Bregman convincingly demonstrated, "Terni's plays constitute an important stage in the development of Hebrew drama and poetry." Terni invented a new meter, based, on the one hand, on contemporary Italian meters, on the other hand, on the traditional Judaeo-Arabic meters of Hebrew poetry, mediated in Italy by the works of Immanuel of Rome. See Bregman, The Glory, 24-33. On Metastasio, see Francesco Paolo Russo, ed., Metastasio nell'Ottocento: Atti del Convegno di Studi Discoteca di Stato, Roma 21 Settembre 1998 (Roma: Arcae, 2003), and David Adam Kirkpatrick, "The Role of Metastasio's Libretti in the Eighteenth Century: Opera as Propaganda" (Ph.D. diss., Florida State University, 2005), Electronic Theses, Treatises and Dissertations. Paper 2883. Accessed 20 May 2016. http://fsu.digital.flvc.org/islandora/object/fsu\%3A181109

${ }^{11}$ The Enhanced Brown-Driver-Briggs Hebrew and English Lexicon: With an Appendix Containing the Biblical Aramaic (Oxford: Clarendon, 1906; electronic edition, 2000), 2515. The electronic edition (2000) of this lexicon was used.

${ }_{12}$ Shimi is mentioned in the following biblical verses: 2 Samuel 16:5, 7, 13; and 19:17, 19, 22, 24; and 1 Kings 2: 8, $36,38,39,40,41,42,44$.

132 Samuel 16:5-14.

14 The biblical text is taken from The Holy Scriptures According to the Masoretic Text: A New Translation: with the Aid of Previous Versions and with Constant Consultation of Jewish Authorities (Philadelphia: The Jewish Publication Society of America, 1917).

152 Samuel 19:17-24

161 Kings 2:8-9.
} 
left the city without the authorization of the king, his destiny was fulfilled, and he was killed. ${ }^{17}$

The name of the dialogue partner of Shimi, Rei, appeared also in the court of King David, but he was never portrayed as vividly as Shimi. The biblical Rei has a steadfast personality, remaining loyal to David during the coup d'état of Adonijah, too. ${ }^{18}$

In contrast to the biblical figures, the protagonists of Terni's play do not have such black-and-white character traits. We cannot say definitely that Shimi of the play is portrayed as a totally hostile personality, he was only tormented by doubts, his courage faltered, and he seems to have been puzzled, while his friend, Rei, seeming to be steadfast and unwavering at first, twice during the play uncovered his most intimate fears.

\section{A psychological analysis of the protagonists in Terni's play}

Terni's drama started with a long monologue from Shimi. The plot of the theatre play took place during the Feast of the Weeks, the traditional holiday commemorating the giving of the Torah to Israel. Shimi began his monologue in this festive atmosphere with a long praisegiving of God because of his mercy for having chosen the Jewish people and having given them the Torah as a gift. But suddenly he stopped praising and started to reveal some ambivalent feelings which had been depressing him for a while:

"I am raising my voice, but woe to me ... why is my spirit groaning?

I would like to sing [praises], but my soul is about to cry.

What kind of a trouble has suddenly affected it?

What kind of suffering 'brought her pains upon her?"'19

He asked himself. ${ }^{20}$ But he quickly revealed the reason for his confusion:

"Oh, yes, my soul! I have just realized [the reason of] your present riddle.

I have just comprehended the great cause that makes you feel bad.

Of the profanation of the name of glorious God you are silently warning me.

Of the desperate status of my people you are reminding me." 21

Seemingly, the miserable condition of contemporary Jewry, living in a prospering Christian environment, made our protagonist sceptical towards the veracity of the traditional claims of Judaism.

"[I am] like a ship without sailors which is driven by two winds." - He confessed.

\footnotetext{
17 Kings 36-44.

${ }^{18} 1$ Kings 1:8. The name of the second protagonist, Rei, used as a common noun, can simply mean the other one, or another person. See Enhanced Brown-Driver-Briggs Hebrew and English Lexicon, 2301.

${ }^{19}$ Bregman, The Glory, 120, lines 53-56. The English translations taken from Terni's drama are mine. The biblical citation at the end of the line comes from 1 Samuel 4:19.

${ }^{20}$ Formerly, in line 49 of the poem, he had already made a slight allusion to a depressive feeling of his: "I will immerse myself in the depths of the joy to get rid of my sorrows." Bregman, The Glory, 120.

${ }^{21}$ Bregman, The Glory, 120, lines 57-60.
} 
"It is sailing slowly, upwards ..., downwards ..., pitching and tossing.

So am I at the moment, because my 'compassion was stirred.'22

My brain and my heart move in contrary directions.

Which of the ways shall I choose, what kind of spirit will bring me rest?

Shall I sing, or shall I keep silence? Oh, my God, ... who will advise me?"23

I think it is worth pondering the words of Shimi for a while. To the best of my knowledge, it is the first point in the long history of Jewish anti-Christian polemical literature, where a sceptical figure appeared on a stage as a man of flesh and blood, as one of us, who had real feelings, who had fears and hopes alike, but who could not, wanted not to conceal his hesitant state of mind. Occasionally Jewish doubters or religious sceptics were portrayed earlier, too, for example, as recently shown by Ora Limor and Israel Yuval, they are described in the famous refutation of Christianity, entitled Sefer Nizzahon ("The Book of Victory"), ${ }^{24}$ penned by the Ashkenazi polemicist, Yom-Tov Lipmann-Mühlhausen, ${ }^{25}$ as early as at the turn of the $15^{\text {th }}$ century. ${ }^{26}$ But in sharp contrast to Terni's theatre play, those figures always remained in the background. Their heretical positions were only formulated and disclosed by the author in order to provide sufficient material for the following rebuttal of their views, but the representatives of the doubts themselves remained shadows of ghosts, embodiments of strange ideas.

Our Shimi is quite different, he is a real human being with hopes and desires, which can appear familiar to all of us, confused by tantalizing doubts and tormented by feelings of uncertainty. In short, he is a real personality. I think by portraying Shimi, the sceptic Jew, as an average human person, as one of us, Matityahu Terni introduced a new perspective into the history of Jewish polemical writings: the psychological approach which remained hitherto unknown and untapped in this genre. Terni's drama showed us that the strange "other one," the "alien" who can be attractive and repulsive at the same time, is located not only outside, but can also be found inside. Inside the community, inside one's psyche. After the Renaissance had discovered the value of human personality, the Baroque started to demonstrate the complexity of this personality.

Our Shimi is not a particularly learned person, his scepticism is not the unbelief of the academic elite of his age, it is also a very far cry from the systematic agnosticism applied by some of the late medieval philosophers; his sceptical attitude was brought about by the length of the exile, by the delay of the arrival of the Messiah, or as he himself put it:

"Comprehend, [my friend], due to the many troubles our soul became powerless.

It has no power left to hold out; our hearts are broken, beaten.

A continual rain beats into powder even the rocks.

\footnotetext{
${ }^{22}$ Hosea 11:8.

${ }^{23}$ Bregman, The Glory, 121, lines 65-70.

${ }^{24}$ The book is not to be confused with the Sefer Nizzahon Yashan ("The Old Book of Victory"), an anonymus $13^{\text {th }}$ century Jewish polemical text originating in Germany. See David Berger, The Jewish-Christian Debate in the High Middle Ages: A Critical Edition of the Nizzahon Vetus, with an introduction, translation and commentary by David Berger (Philadelphia: Jewish Publication Society, 1979).

${ }_{25}$ Yom-Tov Lipmann-Mühlhausen (d. later than 1420) was a late medieval controversialist, kabalist and philosopher. His Nizzahon was composed between 1401 and 1405.

${ }_{26}$ Ora Limor and Israel Jacob Yuval, "Skepticism and Conversion: Jews, Christians, and Doubters in Sefer haNizzahon," in Hebraica Veritas? Christian Hebraists and the Study of Judaism in Early Modern Europe, ed. Allison P. Coudert and Jeffrey S. Shoulson. (Philadelphia: Pennsylvania Press, 2004), 159-180.
} 
In the many combats [we are fighting,] our [best] ranks will fall." ${ }^{27}$

When Rei entered the stage, he met his friend in the depths of despair. In contrast to him, he appeared to be quite self-confident, the exact opposite of Shimi. First, he tried to figure out the cause of Shimi's disillusionment, ${ }^{28}$ but having realized the real reason for his sorrow, to the great surprise of the spectators, he started to tell an interesting dream vision of his. ${ }^{29}$ Were it not an anachronism, I would say, he told a "Freudian dream." In his dream Rei saw himself surrounded by the hostile glances of his Christian compatriots who tried to seduce him to abandon Judaism and embrace Christianity. At the end of his dream, Rei managed to resist the pressure and drove away the hostile Christians. The whole dream scene could have been considered as a mere rhetorical device, employed by the author consciously to enhance the seriousness of the situation, were it not for a second Freudian slip of tongue on Rei's part. But before analysing his second slip, let us turn our attention back to Shimi.

Having managed to calm down Shimi's rebellious emotions, Rei proposed to play a strange game: a kind of "party game of polemic." The rules of the game were simple: one of the players had to present a typical Christian argument against the Jewish religion which the other player had to refuse with cleverly formulated counter-arguments. A strange proposal for a play, indeed! Realizing the weirdness of Rei's proposal, we might be wondering, whether this kind of performance - imitating real disputations among the walls of the yeshiva, granting some sense of security and intimacy - belonged to the ordinary curriculum of an average Italian yeshiva bocher in the age of the ghetto, as a necessary step in their education for life? A question that on the basis of our source alone must remain undecided.

But our protagonist, Shimi did not seem to be an average student of his age, he did not want to toe the line, he anticipated a trap behind the idea of this bizarre game. He tried to refuse this strange invitation in every possible way: "He [Rei] thought he had caught me, but I had trapped him." ${ }^{30}$ - he relieved himself for a moment. But Rei did no abandon his plan, he tried to compel Shimi to play this odd game by all means. "[This time] he [Shimi] managed to escape from my trap into which I wanted to lure him in, but he will fall in soon against his will, he would not be able to run away." ${ }^{1}$ - Rei reassured himself. And indeed, in the following lines - by means of a fraudulent trick - he still managed to convince Shimi to engage with the series of the hostile questions.

This fraudulent, double-dealing behaviour of Rei, portrayed quite honestly by our author, makes us think for a while again. Why was it so important, even necessary for Rei to entice his friend, Shimi, into this unusual game? The answer was nowhere clearly articulated in Terni's play, so we are left alone with our hypotheses. His stratagem can be evaluated in a quite neutral way: dialogue needs at least two dramatis personae; so Rei was forced to get a partner, even by force, whom he would be able to confront.

But it seems to me more logical, and psychologically more correct to look for another explanation, since $R e i$ at this point of the drama was quite aware of the depressing doubts

${ }^{27}$ Bregman, The Glory, 122, lines 93-96.

${ }^{28}$ Bregman, The Glory, 122-123, lines 106-127.

${ }^{29}$ Bregman, The Glory, 123-124, lines 139-155.

${ }^{30}$ Bregman, The Glory, 124, line 171.

${ }^{31}$ Bregman, The Glory, 124, lines 172-173. 
and anxieties of his friend, which, in turn, can be evaluated as representing the most intimate fears of the whole community. Rather, I think he, like a modern-day psychologist, wanted Shimi first to put into words his problem, his inarticulate, disquieting scepticism, in order to be able to treat it. If our interpretation is right, Shimi's role was to give a voice - in a totally legitimate way, since disguised as a game - to the most pressing doubts of an entire Jewish community of the ghetto age.

Finally, Rei threatened Shimi that he would to break off his friendship with him if he continued to refuse to play. ${ }^{32}$ Shimi protested, and Rei proposed to decide the question by lot. Whoever's name would be drawn first, his turn was to start the enumeration of the Christian arguments. The drawing was again nothing but a fraud; Rei cheated his friend, making him believe that his name was chosen, although actually both cards in Rei's pocket held the name of his friend. ${ }^{33}$ At this point in the story Shimi capitulated; he abandoned his opposition and entered into the game. ${ }^{34}$

From this point on the play returned to the normal routine and progressed as a protocol of a regular disputation: ${ }^{35}$ Shimi enumerated well-known Christian arguments against Judaism: a famous one, seeing in the length of the Jews' exile a proof verifying the correctness of Christianity's statements, ${ }^{36}$ another traditional Christian argument interprets the exile as a legitimate punishment of Jews for "their maltreatment of Jesus"; ${ }^{37}$ and a third one claims the abolition of the commandments of the Torah after "Jesus' new revelation." ${ }^{88}$ Rei always gave the familiar Jewish answers to these Christian objections. Later, in accordance with the well-established Jewish explanation for the exile as punishment - not for having crucified Jesus, but for the many sins committed throughout their history - Rei portrayed the whole course of Jewish history in a long description, highlighting the sins of every generation, which resulted in the present-day and seemingly never-ending banishment. ${ }^{39}$

In this way we reached the argument focusing on miracles. ${ }^{40}$ The absence or presence of miracles was often discussed in the polemical texts of the early modern period; miracles could be interpreted as testimonies pro or contra Judaism or Christianity, respectively. ${ }^{41}$ In Terni's play the main Christian argument, put in the mouth of Shimi, read: the presentday cessation of miracles in favour of the Jews - which, if they were present, could be considered as a valid proof of the legitimacy of Judaism - undoubtedly expressed the divine disfavour against the Jews that must have been triggered by the crucifixion of Jesus.

\footnotetext{
${ }_{32}$ Bregman, The Glory, 125-126, lines 188-207.

33 Bregman, The Glory, 131, lines 373-381.

${ }_{34}$ Bregman, The Glory, 126, lines 208-210.

${ }_{35}$ Compare for example the record of Azriel Petahiah (Bonaiuto) ben Moshe Alatino (16 $6^{\text {th }}-17^{\text {th }}$ century), entitled Vikkuah al-Nitzhiyyut ha-Torah ("The Controversy over the Eternity of the Torah"). The text was based on a real disputation between the author and a Jesuit priest, named Alfonso Caracciolo. The disputation took place in Ferrara in the year 1617. The text was edited by Giuseppe Jaré in Livorno, entitled Vikkuah al-Nitzhiyyut ha-Torah (with an added Italian title: Della Immutabilità della Legge Mosaica) (Livorno: I. Costa, 1876).

${ }^{36}$ Bregman, The Glory, 126-127, lines 208-230.

${ }_{37}$ Bregman, The Glory, 127-128, lines 247-266.

${ }^{38}$ We only get to know this argument from the counter-argument of Rei, given in Bregman, The Glory, 129, lines 295-300.

${ }^{39}$ Bregman, The Glory, 129-130, lines 318-346.

${ }^{40}$ Bregman, The Glory, 131-133, lines 363-413.

${ }^{41}$ See, for example Yehuda ben Eliezer Briel's (1643-1722) short treatise, entitled Breve Ragionamento sopra $i$ miracoli (“A Brief Treatise on Miracles"). See Nicholas Patruno and Samuel Tobias Lachs, eds., "A Brief Treatise on Miracles of R. Yehuda Briell," Gratz College Annual of Jewish Studies 3 (1974): 77-82.
} 
Rei refuted this claim with a witty counter-argument, stating that the greatest miracle that ever happened was the continuous existence of the Jewish people in the exile, in spite of so many persecutions, extreme hatred and enmity. ${ }^{42}$ In response Shimi took on the role of a sceptic again, and articulated a question whether miracles still had the power of persuasion. Did they still prove beneficial in religious competitions? Were they still needed at all? ${ }^{43}$ But once again it is Rei's answer that deserves most of our attention: first, he explained that, as a consequence of the Reformation, the Church lost her former appeal among Christians. Christianity disintegrated into several denominations, small or large, which could be united again only through the good offices of a miracle, performed to restore the lost unity. ${ }^{44}$ And, which sounded more striking in the mouth of a consistent defender of the Jewish position, he added in a brief comment, that in case of the appearance of an impressive miracle even the conversion of Jews to Christianity could not be fully ruled out!

How many sects [i.e. the Protestants] their [i.e. the Catholics'] law disgusted.

If they saw a miracle, they would stream to maintain the [unity] of their religion.

And perhaps our people would join them. ${ }^{45}$

The strange idea of a free-will conversion of a Jewish community was never further elaborated in the play; however, the brief allusion to it by Rei does not seem to have been an accident. It could be interpreted as a second "Freudian slip" on the part of our seemingly unwavering friend. From this point on the dialogue returned to its normal course, Shimi's further arguments were always refuted, ${ }^{46}$ until finally, his doubts seem to have dispersed, and at the end of the drama he proudly and confidently sang a rewritten version of Yigdal, the medieval poetical version of the Maimonidean creed, together with his friend, Rei.

\section{Conclusion}

In this article an attempt has been made to portray a popular form of scepticism which, being seemingly quite widespread among different sections of the Jewish populace in $18^{\text {th }}$ century Italy, demanded an adequate answer from the contemporary religious leadership. As I have tried to show, this type of scepticism - a tormented feeling of uncertainty in the face of the course of history - was principally triggered by the historical experience of the length of the exile, and not by any sophisticated philosophical reasoning or academic disbelief.

Coming to the end of our analysis, we have only one question to answer: who are the real protagonists of Terni's play? Which group or segment of the contemporary Jewish community was symbolized by Shimi, and whose alter ego is his friend, Rei? As I tried to

\footnotetext{
${ }^{42}$ Bregman, The Glory, 131, lines 373-381.

${ }^{43}$ Bregman, The Glory, 132-133, lines 410-413.

${ }^{44}$ Bregman, The Glory, 133, line 417.

45 Bregman, The Glory, 133, lines 416-418. Line 418 reads in Hebrew: ובני עמנו לו עמהם יתחברו see also Bregman's comment to this line on page 209.

${ }^{46}$ His arguments concern the miracles of Jesus, his genealogy, resurrection and the problem of the Trinity.
} 
show through the analysis, neither figure could be characterized by black-and-white features, they have more complex personalities. Shimi appeared to be more infected with doubts, more disillusioned, hesitant, losing his self-confidence, standing helpless in the storm of history, living among an arrogant, hostile and supercilious Christian majority. Even though the hostility of the Christian majority was manifested at this time more in words than in deeds, in one point of the dialogue a mention is made of compulsory proselytization of Jewish children, ${ }^{47}$ making Rei's fear not unfounded. In sharp contrast to his friend, Rei appeared to be more steadfast, keeping his self-confidence till the end of the drama where he was juggling with logical arguments in refuting the Christian conception of Trinity. ${ }^{48}$ But, as we have seen, twice his most intimate, "Freudian fears," were also exposed to the public.

I think we are not mistaken if we identify Shimi and Rei in Terni's play as the two "halves of the psyche" of an average Italian Jew of the ghetto age, or two states of mind of the same person. He or she was divided, like the two protagonists of the drama, fluctuating always between these two states; sometimes dominated by doubts, approaching a form of popular scepticism as our Shimi did on the stage, sometimes ruled by the familiar counter-arguments, hoping for a better future, recovering his or her self-confidence as Rei did in the play. However, as we have seen, ultimately this apparent self-confidence was always prone to confusion.

Interpreted this way, the stage play Derech Emunah, whilst not an immortal literary masterpiece, proved to be a genial psychological portrayal of the complex personality of the modern human being on the eve of the Enlightenment. A human being who was already irrevocably infected with doubts, and yet strove to be full of hopes, who sought to be rational, and still was always susceptible to irrational temptations.

\section{BIBLIOGRAPHY}

Alatino, Azriel Pethahiah. Vikkuah al-Nitzhiyyut ha-Torah. Edited by Giuseppe Jaré. Livorno: I. Costa, 1876.

Berger, David. The Jewish-Christian Debate in the High Middle Ages: A Critical Edition of the Nizzahon Vetus. With an introduction, translation and commentary by David Berger. Philadelphia: Jewish Publication Society, 1979.

Bregman, Dvora, ed. The Glory of Sinai: The Dramatic Works of Matityahu Nissim (Donato) Terni [in Hebrew]. Jerusalem: The Ben Zvi Institute and the Hebrew University of Jerusalem, 2003.

Brown, Francis, S. R. Driver, and Charles A. Briggs, eds. The Enhanced Brown-Driver-Briggs Hebrew and English Lexicon: With an Appendix Containing the Biblical Aramaic. Oxford: Clarendon, 1906. Electronic Edition, 2000.

David, Yonah. “M. N. Terni's 'Derech Emunah”” [in Hebrew]. Zehut 2 (1982): 267-286.

Kirkpatrick, David Adam. "The Role of Metastasio's Libretti in the Eighteenth Century: Opera as Propaganda." Ph.D. diss., Florida State University, 2005.

\footnotetext{
${ }_{47}$ Bregman, The Glory, 127, lines 239-241.

${ }^{48}$ Bregman, The Glory, 134-137 lines 473-545.
} 
Lasker, Daniel J. Jewish Philosophical Polemics against Christianity in the Middle Ages. $2^{\text {nd }}$ ed. Oxford: The Littman Library of Jewish Civilization, 2007.

Limor, Ora, and Israel Jacob Yuval, "Skepticism and Conversion: Jews, Christians, and Doubters in Sefer ha-Nizzahon." In Hebraica Veritas? Christian Hebraists and the Study of Judaism in Early Modern Europe, edited by Allison P. Coudert and Jeffrey S. Shoulson, 159-180. Philadelphia: Pennsylvania Press, 2004.

Modena, Yehuda Aryeh. The Autobiography of a Seventeenth-Century Venetian Rabbi: Leon Modena's Life of Judah. Translated and Edited by Mark R. Cohen. Princeton: Princeton University Press, 1988.

Patruno Nicholas, and Samuel Tobias Lachs, eds. "A Brief Treatise on Miracles of R. Yehuda Briell." Gratz College Annual of Jewish Studies 3 (1974): 77-82.

Russo, Francesco Paolo, ed. Metastasio nell'Ottocento: Atti del Convegno di Studi Discoteca di Stato, Roma 21 Settembre 1998. Roma: Arcae, 2003.

Salah, Asher. La République des lettres: Rabbins, écrivains et médecins juifs en Italie au XVIII siècle. Leiden: Brill, 2007.

Schirmann, Hayim. Studies in the History of Hebrew Poetry and Drama [in Hebrew]. 2 vols. Jerusalem: Mosad Bialik, 1979.

Stow, Kenneth. Theater of Acculturation: The Roman Ghetto in the Sixteenth Century. Seattle: The University of Washington Press, 2001.

The Holy Scriptures According to the Masoretic Text: A New Translation: with the Aid of Previous Versions and with Constant Consultation of Jewish Authorities. Philadelphia: The Jewish Publication Society of America, 1917. 